\title{
POLITICAL AND COMMUNICATIVE INTERACTION IN PUBLIC SPACE BETWEEN THE RUSSIAN GOVERNMENT AND THE RUSSIAN ORTHODOX CHURCH: DIRECTIONS AND PRIORITIES ${ }^{1}$
}

\author{
Elena M. Drinova \\ Volgograd State University, Volgograd, Russian Federation
}

\begin{abstract}
Introduction. The aim of the work was to analyze the leading directions of interaction between the state and religious authorities in the modern public space. It is shown that the result of this interaction was the politicization of the Russian Orthodox Church (hereinafter ROC). It is proved that in recent decades the Church continues to exert direct and indirect influence on the state, which, in turn, uses its spiritual potential to stabilize the socio-political system. Methods and materials. Institutional and modernization approaches were used as the research methodology. Within the framework of the institutional approach, an analysis of the interaction of government structures and the ROC in the context of adaptation, cooperation and competition in the course of democratic transformations in the country was carried out. Within the framework of the modernization approach J. Haber formulates the fundamental thesis on the increasing role of religion in a secular (modernizing) society and its strengthening in the national state. Analysis. It is noted that in the 1990s the leading direction of interaction between the state and the ROC was exclusively the political sphere, which was associated with the democratization of public life, the involvement of the clergy in political modernization. At the beginning of the $21^{\text {st }}$ century the state proclaimed a course towards depoliticizing the institution of religion. The activities of political religious parties were prohibited. Subsequently, the ruling United Russia party began to focus on mutually beneficial partnership with the ROC, priority was given to the patriotic education of young people. The result of joint activities of the Main Military-Political Directorate of the Armed Forces of the Russian Federation and the ROC was the formation of a new type of soldier, a bearer of spiritual and moral values, a statesman, defender of the Fatherland. The ROC, as the dominant religious figure in the public space, actively participates in the domestic and foreign policy of the country, challenging other confessional structures. The highest officials of the state and the church share the common values of conservatism, but at the same time, each of them defends its own interests, which initiates the limitation of their mutual support. Results. The state power, together with the ROC, solves internal political problems, including the formation of spiritual, moral, patriotic constants in modern Russian society. In the context of the sanctions policy, the activity of the ROC as a conductor of the "soft power" of the state contributes to the improvement of the countrys image. The result of the interaction of state and religious structures is the formation of a new ideological paradigm based on the principles of religious ethics, conservative values, as well as national identity, patriotism.
\end{abstract}

Key words: state, Russian Orthodox Church, public space, value system, politicization of religion, symphony of power, domestic/foreign policy, "soft power".

Citation. Drinova E.M. Political and Communicative Interaction in Public Space Between the Russian Government and the Russian Orthodox Church: Directions and Priorities. Vestnik Volgogradskogo gosudarstvennogo universiteta. Seriya 4. Istoriya. Regionovedenie. Mezhdunarodnye otnosheniya [Science Journal of Volgograd State University. History. Area Studies. International Relations], 2021, vol. 26, no. 4, pp. 41-53. (in Russian). DOI: https://doi.org/10.15688/jvolsu4.2021.4.4 


\title{
НАПРАВЛЕНИЯ И ПРИОРИТЕТЫ \\ ПОЛИТИКО-КОММУНИКАТИВНОГО ВЗАИМОДЕЙСТВИЯ ОРГАНОВ ВЛАСТИ И РУССКОЙ ПРАВОСЛАВНОЙ ЦЕРКВИ В ПУБЛИЧНОМ ПРОСТРАНСТВЕ СОВРЕМЕННОЙ РОССИИ ${ }^{1}$
}

\author{
Елена Михайловна Дринова \\ Волгоградский государственный университет, г. Волгоград, Российская Федерация
}

\begin{abstract}
Аннотация. Введение. В последние десятилетия в России сформировались прагматичные отношения между государственными органами власти и Русской православной церковью, которая стала ключевым игроком в публичном пространстве страны. РПЦ оказывает как прямое, так и опосредованное влияние на образовательную, военную, внешнеполитическую сферы. Государство в свою очередь использует ее духовный потенциал для стабилизации социально-политической системы, укрепления своего имиджа за рубежом. Meтоды и материалы. В рамках информационно-кибернетического подхода были проанализированы формы социально-политической коммуникации государственных и религиозных акторов. В рамках модернизационного подхода были исследованы проблемы РПЦ в условиях реформирования российского общества. Анализ. Цель статьи - исследование совместной деятельности государственных органов власти и Русской православной церкви в публичном пространстве современной России. Выбор сфер взаимодействия государственных органов власти и Русской православной церкви определен исходя из форм прагматичного сотрудничества, взаимовыгодного партнерства, при этом отмечается, что каждая из сторон отстаивает свои интересы, что порой инициирует ограничение их взаимной поддержки. Результаты. В статье обосновано, что политико-коммуникативное взаимодействие осуществляется на основе системы традиционных ценностей, которые апеллируют к религиозным константам православия, духовности, патриотизму. Отмечается, что данная система, с одной стороны, противостоит западноевропейской демократической системе ценностей, с другой стороны, находит отклик у части консервативного истеблишмента США, Евросоюза. Рассматриваются приоритетные сферы взаимодействия государства и РПЦ. Отмечается роль церкви в распространении консервативных ценностей в политической, армейской и образовательной среде, обсуждаются последствия взаимодействия государственного и религиозного институтов. Исследована роль РПЦ как проводника «мягкой силы» в ряде стран Евросоюза. Отмечается, что одним из каналов по реализации «мягкой силы» выступает Фонд «Русский мир». Показывается, что первоначально это был глобальный светский проект, целью которого выступало формирование российской национальной идентичности. Но со временем «Русский мир» приобрел религиозное звучание. Обсуждается также, что результатом взаимодействия государственных и религиозный структур становится формирование новой мировоззренческой парадигмы, опирающейся на систему консервативных ценностей, национальной идентичности, патриотизма.

Ключевые слова: государство, Русская православная церковь, публичное пространство, система ценностей, политизация религии, симфония власти, внутренняя/внешняя политика, «мягкая сила».

Цитирование. Дринова Е. М. Направления и приоритеты политико-коммуникативного взаимодействия органов власти и Русской православной церкви в публичном пространстве современной России // Вестник Волгоградского государственного университета. Серия 4, История. Регионоведение. Международные отношения. - 2021. - Т. 26, № 4. - C. 41-53. - DOI: https://doi.org/10.15688/jvolsu4.2021.4.4
\end{abstract}

Введение. В последнее десятилетие в России сформировались прагматичные отношения между государством и Русской православной церковью, они стали возможными в результате демократических преобразований, в стране были созданы рыночная экономика, институты демократии, сформировалось гражданское общество. Одним из ключевых игро- ков публичного пространства выступила РПЦ, восстановившая статус доминирующей религии, которая представляет свои интересы в условиях отсутствия конкуренции со стороны религиозных элит иных конфессий страны.

В 2020 г. по инициативе патриарха Кирилла в Конституцию была внесена поправка о вере в Бога, анонсированная Президен- 
том РФ [5; 14]. Согласно данной поправке следует учитывать исторически сложившиеся культурно-религиозные доминанты при проведении внутренней и внешней политики государства. Вместе с тем можно предположить, что данная поправка используется для выстраивания нового тренда - гражданской религии, которая основывается на верховенстве традиционных религий и православия как государствообразующей силы; предполагает доминирование культа государства с опорой на консервативные ценности. Соответственно основной функцией гражданской религии выступает легитимация политической власти.

Что же касается востребованности религиозных ценностей среди россиян, то отметим следующее. В 2019 г. православными себя называли 63 \% опрошенных. При этом из них не посещали церковь $15 \%$ опрошенных; реже одного раза в год - $13 \%$; и один раз в месяц посещали церковь $11 \%$. На вопрос «Как часто вы причащаетесь?» $34 \%$ опрошенных ответило - никогда; $11 \%$ - реже одного раза в год; $14 \%$ - один или несколько раз в год, только $3 \%$ причащалось раз в месяц или чаще [12]. Вместе с тем в христианской традиции причастие означает для верующего символическое и физическое воссоединение с Богом.

Существуют определенные критерии религиозности, к которым относится регулярное посещение церкви, исполнение таинств, чтение священных книг и др. Согласно этим критериям процент православных верующих в стране является минимальным. Для большинства россиян религиозная самоидентификация является скорее отражением их гражданской идентичности, а отнюдь не православной принадлежности. В данном контексте православность рассматривается как признак самоидентификации и отчасти социальной респектабельности российских граждан. Вместе с тем наличие православного идентификационного конструкта в массовом сознании свидетельствует о том, что в России существует религиозность без религии как таковой. Религиозные ценности воспринимаются гражданами скорее в культурном цивилизационном аспекте. Иными словами, религиозность представляет собой систему консервативных ценностей, традиционных идеалов, при- витых государством совместно с РПЦ, при этом используется исключительно организационная составляющая православной религии, а теологическая отходит на задний план [19].

Методы и материалы. Анализ форм социально-политической коммуникации государственных / религиозных акторов был осуществлен в рамках информационно-кибернетического подхода. Согласно К. Дойчу, коммуникация лежит в основе динамических изменений политической системы. Социальные цели достигаются посредством координации, сотрудничества между государственными и религиозными акторами социально-политического процесса. Институциональный подход позволил изучить взаимодействие между государственными структурами и РПЦ, которые преследуют сакральные / светские цели в контексте адаптации, сотрудничества и конкуренции в ходе демократических преобразований [23, p. 132]. В рамках модернизационного подхода основополагающим стал тезис Ю. Хабермаса о возрастающей роли института религии в постсекулярном обществе, усилении ее роли внутри национального государства [18]. Роль института религии в таких обществах увеличивается, что обусловлено переосмыслением человечеством конфликтов, которые имеют религиозную составляющую; усилением института церкви в национальных государствах, где он функционирует в секулярной среде; существованием «чужих» религиозных общин, что заставляет по-новому пересмотреть отношение человека к «своим» церквям.

Следует отметить некую парадоксальность взаимоотношений между государством и РПЦ в России. Чем выше уровень секуляризации в современном государстве, тем активнее политическая элита использует институт религии в качестве новой объединяющей идеологии [28]. Православие как доминирующая в публичном пространстве конфессия активно участвует в социальной политической жизни страны, бросает вызов иным конфессиям [29]. Высшие лица государства и церкви разделяют общие консервативные ценности, но при этом они отстаивают свои интересы, что инициирует ограничение их взаимной поддержки. Вместе с тем в стране сложились условия для формирования отношений в формате симфонии властей [20]. 
Дрейф православия в культурно-образовательную сферу, введение в школе курса по основам православной культуры, поддержка церковных инициатив государством приводит к трансформации церкви, которая в своей деятельности начинает исходить из симбиоза светских и религиозных принципов [16;26; 27]. Государственные органы при проведении культурной образовательной политики в стране учитывают православный компонент, что приводит к размыванию границ светского характера государства.

Согласно Конституции, Россия является светским деидеологизированным государством. Однако сегодня наблюдается выход страны из идеологического вакуума, трендом правящей партии выступает консервативная идеология, в основу которой положены ценности патриотизма, суверенная демократия и православие. Данная идеологическая модель противостоит западной и, соответственно, предполагает защиту от западноевропейских ценностей [9; 24]. Российская модель управления, основанная на традиционных ценностях, усиливает возможности при проведении внешней политики страны. Вместе с тем система ценностей, которые Россия и РПЦ транслируют зарубеж, может сделать страну «лидером нелиберального мира» $[21 ; 25 ; 30]$.

Однако существует и иная точка зрения, согласно которой российский консервативный дискурс нашел отклик у части политической элиты в США, а также ряда политиков США и ЕС, которые скептически относятся к проекту евроинтеграции. Следует отметить, что изначально консерватизм в странах Западной Европы был связан с христианством, моральными ценностями и установкой политической элиты на служение обществу [1]. В XXI в. евроскептицизм был положен в основу программ ряда националистических партий Франции, Германии, Великобритании и др., стал частью политической жизни Европы. С таких позиций евроскептикам более близка российская консервативная модель, основанная на национальном суверенитете, традиционной семье, национальной культуре, религиозности, чем наднациональная мультикультурная модель Брюсселя.

За рубежом государство использует РПЦ в качестве проводника внешнеполити- ческих взглядов государства, как инструмент «мягкой силы». В России акцентируется внимание на информационной пропагандистской составляющей «мягкой силы» [10]. Ряд зарубежных исследователей рассматривает «мягкую силу» России применительно к странам развитой демократии как угрозу их национальной безопасности, отмечают ее экспансивный и манипулятивный характер [32]. Следует отметить, что в 2016 г. Россия впервые вошла в рейтинг 30 стран, использующих «мягкую силу». Однако на протяжении последних лет отмечается падение рейтинга, в итоге она спустилась с 26-го места в 2016 г. до 30-го места в 2019 году [33].

Анализ. Исторически Россия была поликонфессиональным государством. Современная Россия учитывает исторически сложившуюся культурно-историческую роль православной церкви. Конституция закрепляет светский характер государства, запрещает любой религии выступать в качестве «государственной». Обозначенная выше тенденция стала основополагающей при формировании приоритетных направлений органов государственной власти и церкви в публичном пространстве страны.

Направление первое - демократизация социума и политизация религии. Распад СССР, формирование новой государственности, переход к демократии сопровождался возрождением религиозности. Патриарх Всея Руси Алексий, а впоследствии Кирилл заявляли о своей поддержке избранных президентов Б.Н. Ельцина, В.В. Путина, Д.А. Медведева, благословляли их политическую деятельность. Результатом политизации религии, включенности священнослужителей и мирян в политический процесс стало образование политических религиозных партий. Со временем деятельность как христианских, так и исламских политических партий усилила потенциал угроз, связанный с религиозным экстремизмом, а политизация религии стала фактором дестабилизации системы национальной безопасности. Так, например, с 1996 по 2004 г. только в Москве произошло более 20 террористических актов, половина из них была совершена смертниками, в результате более 500 человек погибло, более 800 было ранено. Принятый закон «О политических партиях» 
запрещал создание и деятельность партий по религиозным и национальным признакам.

Отметим, что в дальнейшем политические партии стали придерживаться полярных позиций по проблеме выстраивания государственно-конфессиональных отношений. Партии «Гражданская платформа», «Правое дело» отстаивали принципы секулярного общества, светский характер государства, в том числе его силовых и образовательных структур. Правящая «Единая Россия» стала придерживаться принципов постсекулярного общества, ориентированного на взаимовыгодное партнерство с институтом религии; акцентировать внимание на вере и этнической принадлежности граждан; уделять внимание военнопатриотическому воспитанию. Центристское положение стали занимать КПРФ, «Справедливая Россия», «Яблоко» [8, с. 14].

Позднее российское духовенство заявило о необходимости проведения экономических и политических реформ на основе ценностей православия. Была обоснована идея духовной модернизации в России при участии РПЦ. В Русской доктрине, программном документе была обозначена цель - формирование государственности на основе духовности. Духовная модернизация, на наш взгляд, представляла собой попытку реализации политических амбиций православной церкви, ее стремления стать полноправным актором политического процесса. Позднее РПЦ запретило священнослужителям заниматься политической деятельностью, в то время как православным мирянам было дано такое право, правда только с благословления Синода [15]. Следует отметить, что политизация церкви не есть исключительно новая тенденция, она была обусловлена становлением российского государства, которое во времена кризисов традиционно обращалось к институту религии. Вместе с тем включенность РПЦ в политический процесс инициировала трансляцию консервативных ценностей в публичное пространство страны.

Направление второе. Духовные ценности как основа нравственного потенциала России. Размышляя о духовно-нравственном потенциале российского общества, отметим следующее: его основу составляет феномен патриотизма, формирование позитив- ного отношения граждан к своей Родине, ее защите; уважение к памяти защитников Отечества, активная гражданская позиция, служение и преданность Отечеству. Приоритетным направлением в сфере образования становится формирование духовно-нравственного потенциала в молодежной среде. Следует отметить, что РПЦ длительное время лоббировала включение в государственную систему школьного образования курса «Основы православной культуры», который был официально введен в 2012 г. только после того как Президент РФ Д.А. Медведев поддержал эту инициативу. Включение православного компонента в систему школьного образования, по мнению разработчиков, способствует сохранению национальной и духовной идентичности, укреплению ценностей державности, российской самобытности, стабильности, суверенности. В настоящее время этот курс читается в 4-м классе начальной школы. При этом следует отметить тот факт, что сегодня большая часть учителей, преподающих данный курс в школе, так и родителей, его выбирающих для своих детей, не являются верующими. Как показали результаты опроса ВЦИОМ, большая часть россиян выступает за сохранение принципа светскости государства, желает жить в стране, где религия не оказывает доминирующего влияния на общество и является частным делом граждан [11].

После апробации курса в начальной школе патриархом Кириллом было предложено преподавать его на протяжении всей учебы в школе. Соответственно в 2019 г. Синодальный отдел религиозного образования и катехизации РПЦ разработал примерные образовательные программы по учебному предмету «Православная культура». На изучение курса в начальной школе отводится 102 ч, основные темы - нравственные принципы и нормы в православной культуре, православное искусство, христианская семья; на основное общее образование (5-9 кл.) - 175 ч, упор делается на формирование религиозного мировоззрения, православный образ жизни; на среднее общее образование (10-11 кл.) 70 ч, изучается роль Церкви в современном мире. Но здесь возникает закономерный вопрос, почему бы церкви не увеличить число воскресных школ, в которых можно углублен- 
но изучать данный курс на протяжении длительного времени? Вместо этого церковь стремится расширить свою аудиторию за счет молодого поколения, получающего образование в государственной школе. По нашему мнению, данная тенденция чревата негативными последствиями для самой церкви, происходит ее трансформация, что сопровождается выхолащиванием трансцендентной сущности духовного института.

Отметим, что данный проект РПЦ не был поддержан Министерством просвещения Российской Федерации. В 2021 г. был опубликован Национальный проект «Образование», целью которого провозглашается самореализация и развитие талантов у подрастающего поколения, базовыми составляющими проекта выступают система патриотического воспитания, волонтерское движение, акцент делается на цифровую трансформацию системы образования. Несмотря на конфликт интересов, РПЦ остается выгодным партнером для государственных структур в формировании ценностных моральных установок россиян. Исходя из того, что молодое поколение предопределяет будущее состояние политической элиты страны, РПЦ рассматривается в качестве духовного наставника молодежи, при этом еще закладывает толерантное отношение к церкви.

Формирование патриотических ценностей у молодежи так же происходит в рамках Рождественских чтений, крупнейшего общественного религиозного форума, участие в котором принимают члены правительства, сенаторы, парламентарии. В приветственном слове участникам Рождественских чтений в 2020 г. Президент РФ В.В. Путин отметил вклад РПЦ в укрепление совместной деятельности с государственными органами, институтами гражданского общества в деле сплочения нации и патриотического воспитания молодежи. В рамках Рождественских встреч в Государственной думе проводятся круглые столы, конференции, проходят встречи священнослужителей с лидерами партийных фракций, спикерами верхней и нижней палат парламента, посвященные духовно-нравственному просвещению, патриотическому воспитанию молодежи, формированию христианских ценностей в семье, армии.
Так же православная составляющая имеет место в Вооруженных силах России. Первоначально совместная деятельность РПЦ и армейских структур носила символический характер, заключалась в конструировании и распространении религиозного армейского культа, цель которого - духовная защита российской армии. Так, ракетные войска стратегического назначения получили своего небесного покровителя святую Варвару, Андрей Первозванный стал покровителем Военноморского флота, пророк Илия - покровителем ВДВ, небесным покровителем сухопутных войск стал Александр Невский. Следует отметить, что не все войска имеют своих небесных покровителей, соответственно работа церкви в этом направлении будет продолжена. РПЦ заложила традицию по благословению икон, написанных для российской армии. В Главном храме Вооруженных сил Российской Федерации, сооруженном в 2020 г., проходят церемонии по передаче икон, которые покровительствуют военным структурам.

Приоритетным направлением стало участие РПЦ в реформировании российской армии. Реформы проводились с 2008 по 2020 год. В результате была создана новая структура российской армии, изменилась система военного образования. В аналитическом докладе международного дискуссионного клуба Валдай, посвященном военной реформе, особое место уделялось как формированию нового облика офицера и сержанта, так и отмечалась необходимость разработки новых программ обучения военного состава [3]. На заключительном этапе военной реформы было образовано Главное военно-политическое управление Вооруженных сил. Его задачей является формирование воина-государственника, защитника Отечества, носителя духовно-нравственных ценностей. Как отметил начальник управления генерал-полковник А. Картаполов, Главное военно-политическое управление занимается морально-психологическим обеспечением военнослужащих, поддерживает их моральный и боевой дух, ведет информационно-пропагандистскую работу, создает условия «для реализации права на свободу вероисповедания с учетом особенностей армейской жизни», сохраняет патриотические традиции. По его мнению, военное духовен- 
ство играло «великую роль» в армии России, в современных реалиях ее необходимо вернуть [13].

Институт военного духовенства занимается патриотическим воспитанием в воинских частях, верующие военнослужащие получили возможность исполнять свой религиозный долг. Так же военное духовенство принимало участие в проведении российской операции в Сирии. В местах дислокации российских военных баз были открыты и действовали православные приходы, деятельность которых способствовала усилению сплоченности военнослужащих, снижению постбоевого стресса. Армейские структуры активно поддерживают миссию духовенства и считают, что оно может и обязано заниматься воспитанием духа военнослужащих, при этом возрождение Российского государства связывается ими с возрождением православия.

Результатом совместной деятельности вооруженных сил и РПЦ в 2020 г. стало открытие духовно-просветительского центра при Храме Вооруженных сил РФ. Центр проводит курсы по повышению квалификации по военно-патриотической работе; работает с верующими военнослужащими. Таким образом, РПЦ использует свой потенциал для духовной поддержки, окормления военнослужащих.

Направление третье. РПЦ как канал «мягкой силы». Создатель концепта «мягкой силы» Дж. Най выделил три ее основания - ценности демократии, культура и внешняя политика, используя которые государство приобретает возможность оказывать влияние на другие страны, реализуя при этом свои внешнеполитические цели [31]. В дальнейшем к глобальным ресурсам «мягкой силы» стали относить цифровую инфраструктуру страны, использование цифровой дипломатии; привлекательность экономической модели, достижений национальной культуры; в политической сфере - приверженность ценностям демократии, качество функционирования политических институтов.

В России существует иное понимание «мягкой силы», она представляет собой «комплексный инструментарий решения внешнеполитических задач с опорой на возможности гражданского общества, информационно-коммуникационные, гуманитарные и другие аль- тернативные классической дипломатии методы и технологии» [6]. Российская «мягкая сила» основывается на ценностях консерватизма, которые апеллируют к семейным, религиозным ценностям, сильному государству. Одним из каналов по проведению политики «мягкой силы» является Фонд «Русский мир». В числе его основополагающих задач отметим следующие: сотрудничество с международными государственными, общественными организациями по популяризации русского языка и культуры; поддержку русскоязычных диаспор за рубежом, сохранение культурной идентичности; взаимодействие РПЦ с другими религиями с целью продвижения русской культуры и языка [17]. Первоначально «Русский мир» представлял собой глобальный светский проект, целью которого выступало формирование российской национальной идентичности, что, по мнению его создателей, привело бы к усилению роли России на международной арене. Впоследствии «Русский мир» приобрел выраженный православный окрас. В трактовке патриарха Кирилла понятие «Русский мир» следует рассматривать как цивилизационное, основанное на православной вере. Православные сторонники «Русского мира» позиционируют себя в качестве защитников религиозных ценностей христианской цивилизации. С таких позиций миссией «Русского мира» провозглашалось сдерживание секуляризма, явления, которое, по мнению духовенства, уже охватило Запад.

Так, например, применительно к Украине религиозно-культурный фактор был главной движущей силой действий РПЦ в этой стране. Исторически Киев являлся колыбелью русской цивилизации, где в 988 г. была основана русская православная вера. По мнению российской политической элиты, принятие Украиной западных ценностей может привести к расколу православных, как следствие к краху страны. Вплоть до 2013 г. «Русский мир» как проводник «мягкой силы» был ориентирован на интеграционные процессы между двумя странами; вхождение Украины в общее цивилизационное православное пространство [4]. Политическое звучание концепция «Русский мир» получила после того как Крым вошел в состав России в 2014 году. Президент РФ В.В. Путин обосновал присоеди- 
нение Крыма как событие по «воссоединению русского мира», что тем самым оправдывало нарушение территориальной целостности Украины [7]. Самопровозглашенные Донецкая и Луганская республики, не признанные украинской властью, также апеллировали к ценностному потенциалу «Русского мира». Следует отметить, что с этого периода времени политическая, православная составляющая «мягкой силы» в Украине практически исчерпала себя.

На Балканах политика «мягкой силы» активно реализуется в Сербии, где объединяющим фактором выступают общая славянская идентичность, православная религия. Знаменательным стал визит В.В. Путина в 2019 г. в Сербию. Президент А. Вутич выразил благодарность за помощь в строительстве крупнейшего на Балканах православного собора Святого Саввы, которое было завершено благодаря финансовой помощи из России. Высокая привлекательность «мягкой силы» России на Балканах уходит своим основанием как в общую религию, так и историю народов. Россия выступает и историческим союзником и защитником южных славян.

РПЦ последовательно выстраивает дружеские отношения с православным большинством в Сербии, Болгарии, Греции. Ее ведущим партнером выступает Сербская православная церковь, которая имеет тесные отношения как с Сербским правительством, так и контролирует межцерковные связи с Косово, Черногорией, Хорватией, Сербской Республикой. По мнению западных исследователей, в основу стратегии «мягкой силы» России по большей части были положены антизападные отношения, а не привлекательность русской культуры. Стратегией России на Балканах является предотвращение расширения НАТО, стремление замедлить расширение ЕС и Китая [22].

Во Франции «мягкая сила» основывается на хороших исторических культурных отношениях, наследии Де Голя, считавшего Россию частью Европы. Во Франции действуют два православных фонда, которые продвигают систему консервативных ценностей России, позиционирующей себя защитницей христианской идентичности Европы. В 2014 г. в центральном районе Парижа на набережной
Бранли, напротив Эйфелевой башни, началось строительство православного духовно-культурного центра, который включал в себя Свято-Троицкий собор, приходской центр, франкорусскую начальную школу на 150 человек. В 2016 г. Русский духовно-культурный центр был открыт, что стало большим дипломатическим успехом России и признаком ее «мягкой силы». Инструментами «мягкой силы» так же является религиозная дипломатия, деятельность русских православных церквей на постсоветском пространстве, что способствует повышению престижа России [2]. «Мягкая сила» в условиях санкций дает возможность России выстраивать долгосрочные отношения с европейскими странами, укрепляя при этом свой имидж на международной арене.

Результаты. Приоритетными направлениями совместной деятельности государственных органов и РПЦ выступают образовательная, военная и внешнеполитическая сферы. В образовательной сфере совместная деятельность предполагает формирование духовно-нравственного потенциала в детской, подростковой, молодежной среде. Широкий спектр взаимодействия государственных и религиозных органов власти в публичном пространстве страны находит отражение в проведении Рождественских парламентских чтений, в рамках которых проходят конференции и круглые столы по формированию духовно-нравственного воспитания подрастающего поколения. Вместе с тем в образовательном пространстве страны происходит смешение светских патриотических традиций с религиозными православными, что сопровождается секуляризацией и приводит к трансформации духовного института, выхолащиванию его трансцендентно-имманентной сущности.

В военно-политической сфере глобальным трендом выступает воспитание воинов патриотов, защитников отечества, носителей традиционных ценностей, духовности. В условиях ведения современных гибридных войн, информационной контрпропаганды возрастает риск деморализации воинского состава. Главное военно-политическое управление Вооруженными силами Российской Федерации, отвечающее за идеологическое направление, совместно с институтом военных капелланов проводят политику, направленную на форми- 
рование морального облика военнослужащего. Новой формой сотрудничества Министерства обороны и РПЦ является обеспечение национальной безопасности.

Консолидирующим политическим концептом предстает «Русский мир», который стал краеугольным камнем российской «мягкой силы». Как политическое понятие «Русский мир» используется государственными структурами для укрепления национальной безопасности, восстановления статуса России как великой державы, усиления ее влияния на постсоветском пространстве. В религиозном аспекте «Русский мир» выступает хранителем традиционных ценностей христианской цивилизации, основу которой составляют Россия, Молдова, Беларусь, Украина. Православные сторонники «Русского мира» полагают, что его миссия - вторая христианизация Руси, десекуляризация современного общества; трансляция консервативных ценностей и сдерживание секуляризма в Европе. С таких позиций РПЦ рассматривает государство в качестве инструмента для достижения поставленных целей. Российский дискурс «мягкой силы» востребован у части консервативного истеблишмента США и Евросоюза. Часть западноевропейской консервативно настроенной элиты принимают российскую модель «мягкой силы». Следует отметить, что в ряде восточноевропейских стран, где исторически консолидирующим фактором выступали общая славянская идентичность и православие, политики ориентированы на сближение и сотрудничество с Россией.

Поправки, внесенные в Конституцию в 2020 г., закрепляют формирование новой российской идеологической модели, основу которой составляют патриотизм, система консервативных ценностей. Результатом взаимодействия государственных и религиозный структур становится формирование гражданской религии и новой мировоззренческой парадигмы, опирающейся на принципы религиозной этики; традиционных ценностей, национальной идентичности, патриотизма.

\section{ПРИМЕЧАНИЕ}

${ }^{1}$ Исследование выполнено при финансовой поддержке РФФИ и Администрации Волгоградс- кой области в рамках научного проекта № 19-411340006 p а «Социально-политическое проектирование публичного пространства и системы массовой коммуникации в регионах РФ (на примере Волгоградской области)».

The study was funded by RFBR and the government of Volgograd region according to the research project № 19-411-340006 r_a "Socio-political design of public space and mass communication system in the regions of the Russian Federation (the example of the Volgograd region)".

\section{СПИСОК ЛИТЕРАТУРЫ}

1. Бер, К. Консерватизм: многогранное понятие. Попытка описания и ограничения - поиски следов / К. Бер // Исторические исследования. 2016. - № 5. - C. 10-28.

2. Будаев, А. В. «Мягкая сила» во внешней политике России: истоки, особенности, перспективы / А. В. Будаев // Государственное управление. Электронный вестник. - 2015. - № 48. - Электрон. текстовые дан. - Режим доступа: http://e-journal. spa.msu.ru/uploads/vestnik/2015/vipusk_48. fevral_2015_g. /pravovie_i_polititcheskie aspekti_upravlenija/budaev.pdf(дата обращения: 15.05.2020). - Загл. с экрана.

3. Военная реформа: на пути к новому облику российской армии. Аналитический доклад международного дискуссионного клуба «Валдай». - Электрон. текстовые дан. - Режим доступа: https://ru.valdaiclub.com/files/22561/ (дата обращения: 21.02.2020). - Загл. с экрана.

4. Донцев, С. П. Религиозно-политический конфликт на Украине в контексте российских проектов «мягкой силы» в 1990-2017 гг. / С. П. Донцев // Вестник РГГУ. Серия «Политология. История. Международные отношения. Зарубежное регионоведение. Востоковедение». - 2018. - № 2 (12). - С. 71-91. DOI: https://doi.org/10.28995/2073-6339-2018-2-79-91.

5. Закон РФ о поправке к Конституции Российской Федерации от 14.03.2020 г. № 1-ФКЗ «О совершенствовании регулирования отдельных вопросов организации и функционирования публичной власти». Электрон. текстовые дан. - Режим доступа: http://www. consultant.ru/.cons/cgi/online.cgi?req $=$ doc\&base $=$ LAW\&n $=346019 \&$ fld $=134 \& d s t=1000000001,0 \&$ rnd $=0.40642575178824414 \# 07762658172629764$ (дата обращения: 02.05.2020). - Загл. с экрана.

6. Концепция внешней политики Российской Федерации от 12.02.2013 // Официальный сайт МИД РФ. - Электрон. текстовые дан. - Режим доступа: https://www.mid.ru/foreign policy/official documents/-asset_publisher/CptICkB6BZ29/content/id/ 122186 (дата обращения: 12.12.2020). - Загл. с экрана. 
7. Кудорс, А. «Русский мир» от концепции «мягкой силы» до обоснования войны / А. Кудорс. - Электрон. текстовые дан. - Режим доступа: http://inosmi.ru/sngbaltia/20150417/227571026.html (дата обращения: 16.03.2020). - Загл. с экрана.

8. Лаврентьев, С. Н. Политические партии и постсекулярный синдром в современной России / С. Н. Лаврентьев // Власть. - 2013. - № 12. - С. 14-15.

9. Ларюэль, М. Мягкая сила России: источники, цели и каналы влияния / М. Ларюэль. - Электрон. текстовые дан. - Режим доступа: http: https:// www.ifri.org/sites/default/files/atoms/files/laruelle_ russia_soft_power_ru_2021.pdf. (дата обращения: 25.02.2020). - Загл. с экрана.

10. Лебедева, М. М. «Мягкая сила»: понятие и подходы / М. М. Лебедева // Вестник МГИМО-Университета. - 2017. - № 3 (54). - С. 212-223. - DOI: https://doi.org/10.24833/2071-8160-2017-3-54-212-223.

11. Опрос ВЦИОМ. - Электрон. текстовые дан. - Режим доступа: https://wciom.ru/index.php?id $=236 \& u i d=115295$ ) (дата обращения: 11.02.2020).Загл. с экрана.

12. Опрос ФОМ. 2019 г. Считаете ли вы себя верующим человеком? И если да, то к какому вероисповеданию (конфессии) вы себя относите? Электрон. текстовые дан. - Режим доступа: https:// fom.ru/TSennosti/14128 (дата обращения: 09.11.2020). Загл. с экрана.

13. Право первым подняться в атаку. - Электpoн. текстовые дан. - Режим доступа: https://vpknews.ru/sites/default/files/pdf/VPK_35_748.pdf(дата обращения: 11.02.2020). - Загл. с экрана.

14. Патриарх Кирилл: «Если в гимне может быть “Богом хранимая родная земля”, почему об этом не может быть сказано в нашей конституции». - Электрон. текстовые дан. - Режим доступа: https://www.sova-center.ru/religion/discussions/ authorities/2020/02/d42018/ (дата обращения: 16.06.2020). - Загл. с экрана.

15. Практика заявлений и действий иерархов, духовенства, монашествующих и мирян во время предвыборных кампаний. Проблема выдвижения духовенством своих кандидатур на выборах // Официальный сайт Московского Патриархата. Русская Православная Церковь. - Электрон. текстовые дан. - Режим доступа: http://www.patriarchia.ru/db/text/1400896.html. (дата обращения: 18.12.2020). - Загл. с экрана.

16. Рогинская, М. А. Православная модернизация как предельный интерес: о некоторых аспектах диалога церкви и общества / М. А. Рогинская // Культура и цивилизация. - 2012. - № 5. - С. 91-92.

17. Фонд «Русский мир» создан во исполнение Указа Президента РФ В.В. Путина от 21 июня 2007 года. - Электрон. текстовые дан. - Режим доступа: https://russkiymir.ru/fund/ (дата обращения: 29.11.2020). - Загл. с экрана.
18. Хабермас, Ю. Против «воинствующего атеизма». Постсекулярное общество - что это такое? / Ю. Хабермас. - Электрон. текстовые дан. Режим доступа: http://www.russ.ru/pole/Protivvoinstvuyuschego-ateizma (дата обращения: 30.12.2020). - Загл. с экрана.

19. Adamsky, D. The Role of the Russian Orthodox Church in Moscow's Syrian Campaign / D. Adamsky // PONARS Eurasia. - February 10, 2020. - Electronic text data. - Mode of access: https:// www.ponarseurasia.org/wp-content/uploads/ attachments/Pepm635_Adamsky_Feb2020.pdf(date of access: 24.02.2020). - Title from screen.

20. Anderson, J. Putin and the Russian Orthodox Church: Asymmetric Symphonia? / J. Anderson // Journal of International Affairs. - 2007. - № 61 (1). - P. 185-201.

21. Antunez, J. C. The role of religion and values in russian policies: the-case of hybrid warfare / J. C. Antunez. - Electronic text data. - Mode of access: https://global-strategy.org/the-role-ofreligion-and-values-in-russian-policies-the-case-ofhybrid-warfare/\#_ftn14 (date of access: 25.02.2020). Title from screen.

22. Bechev, D. Russia's Strategic Interests and Tools of Influence in the Western Balkans / D. Bechev // NATO Strategic Communications Centre of Excellence. - 2019. - Electronic text data. - Mode of access: https://www.stratcomcoe.org/russiasstrategic-interests-and-tools-influence-westernbalkans (date of access: 13.01.2021). - Title from screen.

23. Cesari, J. Religion and democratisation: when and how it matters / J. Cesari // Journal of Religious and Pilitical Practice. - 2016. - № 2 (2). - P. 131-134.

24. Curanovic, A. The Attitude of the Moscow Patriarchate towards Other Orthodox Churches / A. Curanovic // Religion, State and Society. - 2007.№ 35 (4). - P. 301-318. - DOI: https://doi.org/10.1080/ 09637490701621679.

25. Curanovic, A. A. Russia's Mission in the World. The Perspective of the Russian Orthodox Church / A. A. Curanovic // Problems of PostCommunism. - 2019. - № 66 (4). - P. 253-267. DOI: https://doi.org/10.1080/10758216.2018.1530940.

26. Clay, E. Multiculturalism and Religious Education in the Russian Federation: The Fundamentals of Religious Cultures and Secular Ethics / E. Clay // State, Religion and Church. 2015. - № 2 (1). - P. 44-74.

27. Eremin, A. The Education Activity of the Russian Orthodox Church in the Contemporary Transcultural Space of Russia / A. Eremin // Procedia - Social and Behavioral Sciences. - 2017. - № 237 (2). - P. 1475-1481. DOI: https://doi.org/10.1016/j.sbspro.2017.02.232.

28. Inglehart, R. F. Giving Up on God. The Global Decline of Religion / R. F. Inglehart // Foreign Affairs. 2020. - № 99 (5). - P. 111-112. - Electronic text data. - 
Mode of access: https://www.foreignaffairs.com/node/ 1126301 (date of access: 01.02.2020). - Title from screen.

29. Köllner, T. Businessmen, Priests and Parishes: Religious Individualization and Privatization in Russia / T. Köllner // Archives de sciences sociales des religions. - 2013. - Vol. 162, № 2. - P. 37-53. - DOI: https://doi.org/10.4000/assr.25037.

30. Kaczmarska, K. B. Conservative soft power: Liberal soft power bias and the 'hidden' attraction of Russia / K. B. Kaczmarska, V. Keating // Journal of International Relations and Development. - 2019. Vol. 22, № 1, pp. 1-27. - DOI: https://doi.org/10.1057/ s41268-017-0100-6.

31. Nye, J. S. Soft Power: The Means to Success in World Politics / J. S. Nye. - N. Y. : Public Affairs, 2004. - $191 \mathrm{p}$.

32. Petro, N. Russia's Orthodox Soft Power / N. Petro // Carnegie Council for Ethics in International Affairs. - 2015. - 23 March. - Electronic text data. Mode of access: https://papers.ssrn.com/sol3/papers. cfm?abstract_id=3172378 (date of access: 30.12 .2020 ). Title from screen.

33. Portland. Soft Power 30. - Electronic text data. - Mode of access: https://softpower30.com (date of access: 14.02.2020). - Title from screen.

\section{REFERENCES}

1. Ber K. Konservatizm: mnogogrannoe ponyatie. Popytka opisaniya i ogranicheniya - poiski sledov [Conservatism: An Opaque and Shimmery Notion. Outlines of a Description of a Notion and an Enclosure of Meaning]. Istoricheskie issledovaniya [History Studies], 2016, no. 5, pp. 10-28.

2. Budaev A.V. «Myagkaya sila» vo vneshnej politike Rossii: istoki, osobennosti, perspektivy ["Soft Power" in Russian Foreign Policy: Origins, Features, Prospects]. Gosudarstvennoe upravlenie. Elektronnyj vestnik [E-journal. Public Administration], 2015, vol. 48. URL: http://e-journal.spa.msu.ru/uploads/vestnik/ 2015/vipusk_48. fevral_2015_g._pravovie_i polititcheskie_aspekti_upravlenija/budaev.p. $\overline{d f}$ (accessed 15 May 2020).

3. Voennaya reforma: na puti $k$ novomu obliku rossijskoj armii. Analiticheskij doklad mezhdunarodnogo diskussionnogo kluba «Valdaj» [Military Reform: Toward the New Look of the Russian Army. Valdai Discussion Club Analytical Report]. URL: https://ru.valdaiclub.com/files/22561 (accessed 21 February 2020).

4. Doncev S.P. Religiozno-politicheskij konflikt na Ukraine v kontekste rossijskih proektov «myagkoj sily» v 1990-2017 gg. [Religious and Political Conflict in Ukraine in the Context of Russian Projects of "Soft Power" in 1990-2017]. Vestnik RGGU. Seriya
«Politologiya. Istoriya. Mezhdunarodnye otnosheniya. Zarubezhnoe regionovedenie. Vostokovedenie», 2018, no. 2 (12), pp. 71-91. DOI: https://doi.org/10.28995/2073-6339-2018-2-79-91.

5. Zakon RF o popravke $k$ Konstitutsii Rossiyskoy Federatsii ot 14.03.2020 g. № 1-FKZ "O sovershenstvovanii regulirovaniya otdelnykh voprosov organizatsii $i$ funktsionirovaniya publichnoy vlasti» [Law of the Russian Federation on Amendments to the Constitution of the Russian Federation of March 14, 2020 No. 1-FKZ “On Improving the Regulation of Certain Issues of the Organization and Functioning of Public Authorities"]. URL: http:// www.consultant.ru/.cons/cgi/online.cgi?req $=$ doc\& base $=$ LAW\&n $=346019 \&$ fld $=134 \& d s t=1000000001,0 \&$ $\mathrm{rnd}=0.40642575178824414 \# 07762658172629764$ (accessed 2 May 2020).

6. Koncepciya vneshnej politiki Rossijskoj Federacii ot 12.02.2013 [Concept of the Foreign Policy of the Russian Federation Febuary 12, 2003]. Oficialnyj sajt MID RF [Website of The Ministry of Foreign Affairs of the Russian Federation]. URL: https:// www.mid.ru/foreign_policy/official_documents/-/ asset_publisher/CptICkB6BZ29/content/id/122186 (accessed 12 December 2020).

7. Kudors A. "Russkij mir» ot koncepcii «myagkoj sily» do obosnovaniya vojny ["Russian World" - From the Concept of "Soft Power" to the Justification of War]. URL: http://inosmi.ru/sngbaltia/ 20150417/227571026.html (accessed 16 March 2020).

8. Lavrentev S.N. Politicheskie partii i postsekulyarnyj sindrom v sovremennoj Rossii [Political Parties and Post-Secular Syndrome in the Modern Russia]. Vlast, 2013, no. 12, pp. 14-15.

9. Laryuel M. Myagkaya sila Rossii: istochniki, celi i kanaly vliyaniya [Russian Soft Power: Sources, Goals and Channels of Influence]. URL: https://www. ifri.org/sites/default/files/atoms/files/laruelle_russia soft power ru 2021.pdf(accessed 25 February 2020).

10. Lebedeva M.M. «Myagkaya sila»: ponyatie i podhody ["Soft Power": Concept and Approaches]. Vestnik MGIMO-Universiteta, 2017, no. 3(54), pp. 212223. DOI: https://doi.org/10.24833/2071-8160-2017-354-212-223.

11. Opros VTSIOM [VCIOM Poll]. URL: https:// wciom.ru/index.php?id=236\&uid=115295 (accessed 11 February 2020).

12. Opros FOM. 2019 g. Schitaete li vy sebya veruyushchim chelovekom? I esli da, to k kakomu veroispovedaniyu (konfessii) vy sebya otnosite? [FOM Poll, 2019. Do You Consider Yourself a Religious Person? If so, What Religion (Denomination) Do You Belong to?]. URL: https://fom.ru/TSennosti/14128 (accessed 9 November 2020).

13. Pravo pervym podnyat'sya v ataku [The Right to be the First to Attack]. URL: https://vpk-news.ru/ 
sites/default/files/pdf/VPK_35_748.pdf (accessed 11 February 2020).

14. Patriarh Kirill: «Esli v gimne mozhet byt "Bogom hranimaya rodnaya zemlya", pochemu ob etom ne mozhet byt skazano v nashej konstitucii»" [Patriarch Kirill: "If the Anthem Says The Native Land So Kept by God Why Cant it be Said in Our Constitution?"]. URL: https://www.sova-center.ru/ religion/discussions/authorities/2020/02/d42018 (accessed 16 June 2020).

15. Praktika zayavlenij i dejstvij ierarhov, duhovenstva, monashestvuyushchih i miryan vo vremya predvybornyh kampanij. Problema vydvizheniya duhovenstvom svoih kandidatur na vyborah [The Practice of Statements and Actions of Hierarchs, Clergy, Monks and Laity During Election Campaigns. The Problem of Clergy Nominating their Candidates for Elections]. Oficialnyj sajt Moskovskogo Patriarhata. Russkaya Pravoslavnaya Cerkov [Russian Orthodox Church. Official Website of the Moscow Patriarchate]. URL: http: //www.patriarchia.ru /db/text/1400896.html (accessed 18 December 2020).

16. Roginskaya M.A. Pravoslavnaya modernizaciya kak predelnyj interes: o nekotoryh aspektah dialoga cerkvi i obshchestva [Orthodox Modernization as the Ultimate Concern: The Dialogue on Some Aspects of Church and Society]. Kultura i civilizaciya [Culture and Civilization], 2012, no. 5, pp. 91-92.

17. Fond "Russkij mir» sozdan vo ispolnenie Ukaza Prezidenta RF V.V. Putina ot 21 iyunya 2007 goda [The "Russkiy Mir" Foundation was Established in Accordance with the Decree of the President of the Russian Federation Vladimir Putin of June 21, 2007]. URL: https://russkiymir.ru/fund (accessed 29 November 2020).

18. Khabermas Yu. Protiv «voinstvuyushhego ateizma». Postsekulyarnoe obshhestvo - chto eto takoe? [Against "Militant Atheism". A Post-Secular Society-What Does That Mean?]. URL: http: //www. russ.ru/pole/Protiv-voinstvuyuschego-ateizma (accessed 30 December 2020).

19. Adamsky D. The Role of the Russian Orthodox Church in Moscow's Syrian Campaign. PONARS Eurasia. February 10, 2020. URL: https:// www.ponarseurasia.org/wp-content/uploads/ attachments/Pepm635_AdamskyFeb2020.pdf (accessed 24 February 2020).

20. Anderson J. Putin and the Russian Orthodox Church: Asymmetric Symphonia? Journal of International Affairs, 2007, no. 61 (1), pp. 185-201.

21. Antunez J.C. The Role of Religion and Values in Russian Policies: The-Case of Hybrid Warfare. URL: https//global-strategy.org/the-role-of-religion-andvalues-in-russian-policies-the-case-of-hybrid-warfare/ \#_ftn14 (accessed 25 February 2020).

22. Bechev D. Russia's Strategic Interests and Tools of Influence in the Western Balkans. NATO Strategic Communications Centre of Excellence. 2019. URL: http://www.stratcomcoe.org/russias-strategicinterests-and-tools-influence-western-balkans (accessed 13 January 2021).

23. Cesari J. Religion and Democratisation: When and How It Matters. Journal of Religious and Political Practice, 2016, no. 2(2), pp. 131-134.

24. Curanovic A. The Attitude of the Moscow Patriarchate Towards Other Orthodox Churches. Religion, State and Society, 2007, no. 35 (4), pp. 301318. DOI: https://doi.org/10.1080/09637490701621679.

25. Curanovic A.A. Russias Mission in the World. The Perspective of the Russian Orthodox Church. Problems of Post-Communism, 2019, no. 66 (4), pp. 253267. DOI: https://doi.org/10.1080/10758216.2018.1530940.

26. Clay E. Multiculturalism and Religious Education in the Russian Federation: The Fundamentals of Religious Cultures and Secular Ethics. State, Religion and Church, 2015, no. 2(1), pp. 44-74.

27. Eremin A. The Education Activity of the Russian Orthodox Church in the Contemporary Transcultural Space of Russia. Procedia-Social and Behavioral Sciences, 2017, no. 237 (2), pp. 1475-1481. DOI: https://doi.org/10.1016/j.sbspro.2017.02.232.

28. Inglehart R.F. Giving Up on God. The Global Decline of Religion. Foreign Affairs, 2020, no. 99 (5), pp. 111-112. URL: https://www.foreignaffairs.com/ node/1126301 (accessed 1 February 2020).

29. Köllner T. Businessmen, Priests and Parishes: Religious Individualization and Privatization in Russia. Archives de Sciences Sociales des Religions, 2013, vol. 162, no. 2, pp. 37-53. DOI: https://doi.org/10.4000/ assr.25037.

30. Kaczmarska K.B., Keating V. Conservative Soft Power: Liberal Soft Power Bias and the Hidden Attraction of Russia. Journal of International Relations and Development, 2019, vol. 22, no. 1, pp. 1-27. DOI: https:// doi.org/10.1057/s41268-017-0100-6.

31. Nye J.S. Soft Power: The Means to Success in World Politics. New York, Public Affairs, 2004. 191 p.

32. Petro N. Russia's Orthodox Soft Power. Carnegie Council for Ethics in International Affairs. March, 23 2015. URL: https://papers.ssrn.com/sol3/ papers.cfm?abstract_id=3172378 (accessed 30 December 2020).

33. Portland. Soft Power 30. URL: https:// softpower30.com (accessed 14 February 2020). 
E.M. Дринова. Направления и приоритеты политико-коммуникативного взаимодействия органов власти и РПЦ

\section{Information About the Author}

Elena M. Drinova, Candidate of Sciences (Philosophy), Associate Professor, Department of International Relations, Political Science and Area Studies, Volgograd State University, Prosp. Universitetsky, 100, 400062 Volgograd, Russian Federation, drinova_em@volsu.ru, https://orcid.org/0000-0001-6927-0242

\section{Информация об авторе}

Елена Михайловна Дринова, кандидат философских наук, доцент кафедры международных отношений, политологии и регионоведения, Волгоградский государственный университет, просп. Университетский, 100, 400062 г. Волгоград, Российская Федерация, drinova_em@volsu.ru, https://orcid.org/0000-0001-6927-0242 